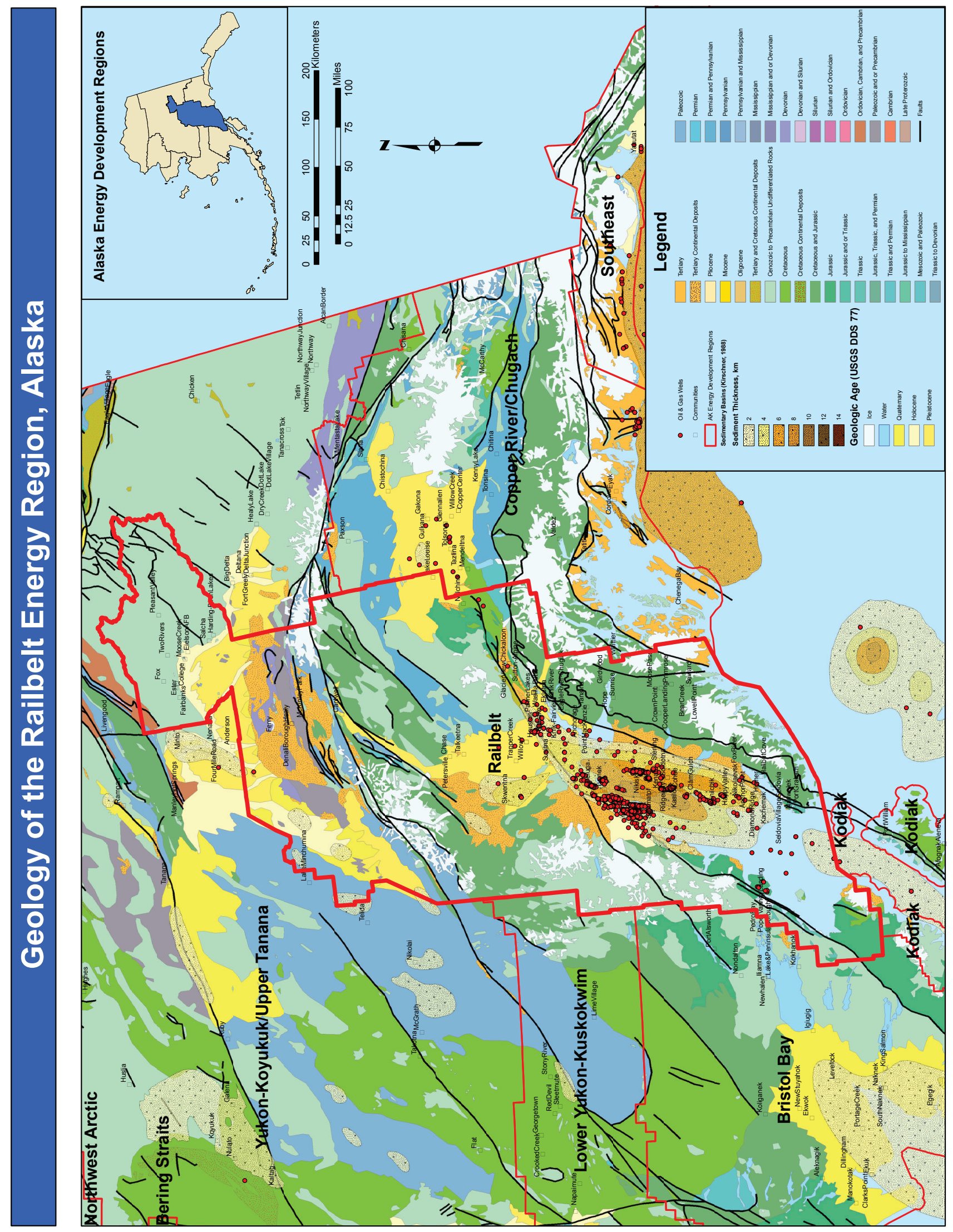





\section{SUMMARY OF FOSSIL FUEL AND GEOTHERMAL RESOURCE POTENTIAL IN THE RAILBELT ENERGY REGION}

by Paul L. Decker, Robert J. Gillis, Ken Helmold, and Shaun Peterson

\section{INTRODUCTION}

\section{Purpose of this report}

Economic growth and stability in Alaska's rural areas hinges partially, if not primarily, on the availability of affordable and sustainable energy supplies. Recent price increases in oil and gas commodities have created severe economic hardship in many areas of the state that are dependent on diesel and heating oil as their primary source of energy. All sectors of Alaska's economy rely on affordable energy sources with limited price volatility, highlighting the need to diversify the energy portfolio by developing locally available and sustainable resources that are not tied to the global market. Unfortunately, all areas are not created equal in energy accessibility; the resources available for local exploitation vary widely across the state. It is critical that funding decisions for expensive programs to reduce the dependence on diesel for heat and electricity take into account information concerning the entire suite of natural resources that exist in a given area.

This report draws from existing information to provide community and state leaders an objective summary of our current knowledge concerning the potential of locally exploitable fossil fuel and geothermal energy resources in the Railbelt Energy Region (fig. J1), one of 11 regions recognized by the Alaska Energy Authority (AEA) in their Energy Plan (AEA, 2009). The potential geologically hosted energy resources considered here include exploitable coal, conventional and unconventional oil and gas, and geothermal resources. This report concludes with recommendations as to what additional data or strategies, if any, would provide the most leverage in helping to develop new energy resources in the region.

Readers without geological training are encouraged to peruse the geologic summaries of fossil fuel resources and geothermal energy in Chapter A. They provide an overview of the geologic elements that must be present in an area to economically develop coal, conventional oil and gas, unconventional oil and gas, and geothermal resources. These summaries will provide the necessary background to more fully understand the information presented in this chapter.

\section{Geographic and geologic setting}

The Railbelt Energy Region covers approximately 72,526 square miles of south-central and central interior Alaska, encompassing most of the major Alaska population centers, and a significant portion of the main Alaska transportation corridors including rail, road, and maritime routes (sheet 1). The development region extends from the upper Alaska Peninsula just south of Kamishak Bay and the southernmost Kenai Peninsula, on its southern end, to the White Mountains north of Fairbanks on its northern end. The development region is bounded to the west by the spine of the southern Alaska Range, the western boundary of Denali National Park, and the eastern margin of Minto Flats. To the east, it extends to just west of Prince William Sound, and is bounded by

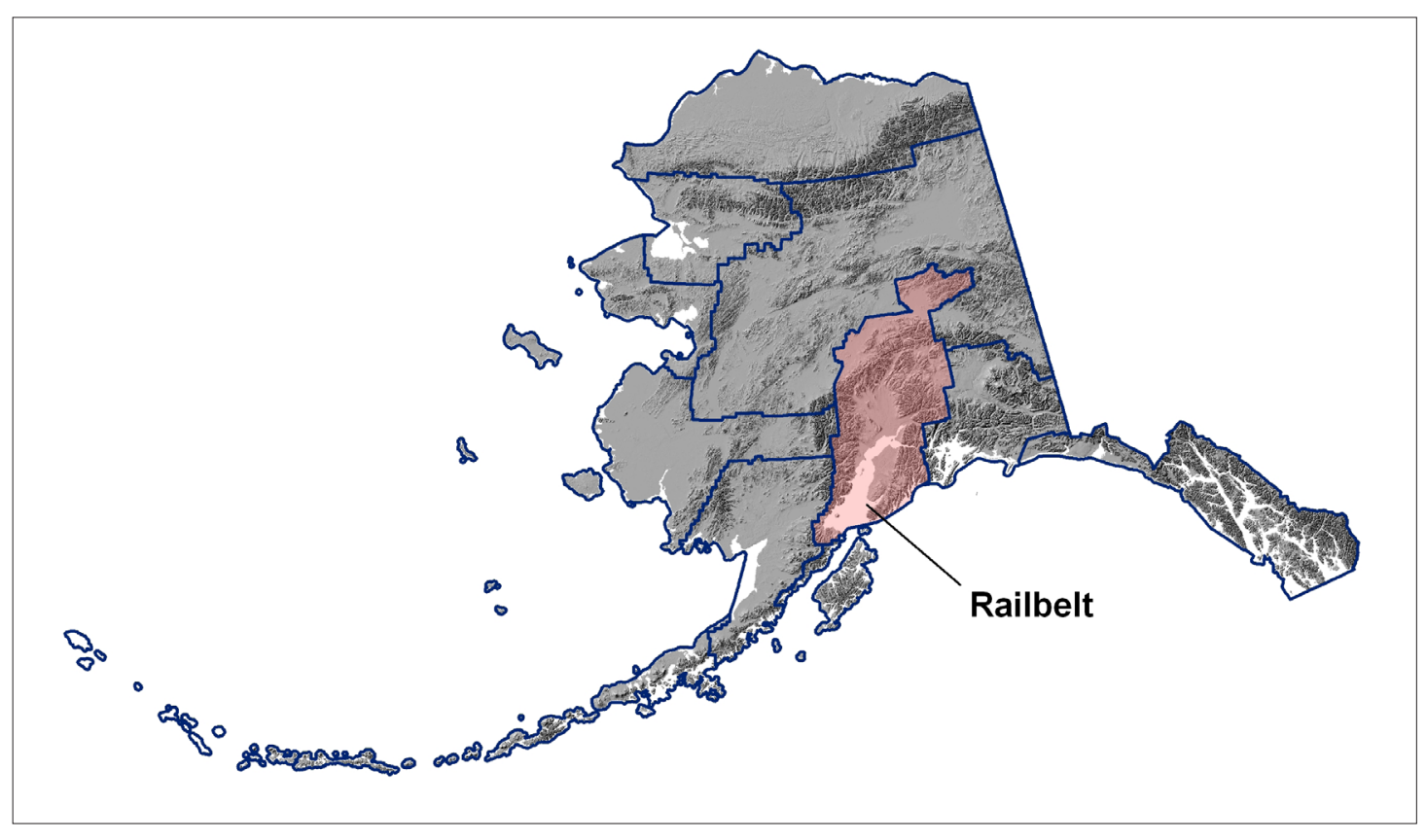

Figure J1. Location map of Railbelt Energy Region. 
approximately the western boundaries of the Copper River basin, Fort Greely, and the Yukon-Charley Rivers National Preserve. The largest population center in the Railbelt Energy Region is the municipality of Anchorage, which also includes the community of Eagle River, for a total of approximately 284,000 residents. The majority of the remaining population is found in three large boroughs: the Fairbanks North Star Borough $(\sim 97,000)$, the Matanuska-Susitna Borough $(\sim 80,000)$, and the Kenai Peninsula Borough $(\sim 52,000)$. The Fairbanks North Star Borough is anchored by the city of Fairbanks and other communities with between 2,000 and 12,000 people, such as College, Eielson Air Force Base, Ester, and North Pole. The Matanuska-Susitna Borough includes a large number of small communities of fewer than 10,000 people, including Wasilla, Palmer, and Houston. The Kenai Peninsula Borough is similarly composed of a large number of smaller communities, including Kenai, Homer, Nikiski, Soldotna, and Seward. Towns along the Parks Highway near Denali National Park include Cantwell, McKinley Park, Healy, Ferry, and Anderson with a combined population of about 2,000. The development region also includes many smaller, outlying villages with fewer than 200 people.

The Railbelt Energy Region encompasses a diverse assortment of physiographic and geologic settings ranging from rugged, glaciated mountain ranges, to solitary volcanoes, rolling hills, and coastal and interior lowlands. Major mountainous areas in the region include the Alaska Range and Kenai, Chugach, and Talkeetna mountains. These elevated regions are flanked by Tertiary sedimentary basins such as the Cook Inlet, Susitna, and Nenana basins, each of which contains significant known coal resources and energy potential. The petroleum potential of these basins is variable with the Cook Inlet area having produced significant volumes of hydrocarbons, whereas the more interior basins remain only lightly explored. The region also includes limited areas prospective for geothermal development, such as the Mount Spurr and Chena Hot Springs areas. Each of these physiographic features and potential energy resources are an expression and direct consequence of ancient and ongoing tectonic, erosional, and biologic processes that have been shaping the landscape for about the last 200 million years. Some of the most prominent topographic features of the Railbelt: the Kenai-Chugach Mountains, Cook Inlet basin, the southern Alaska Range, and volcanic centers such as mounts Iliamna, Redoubt, and Spurr, are the result of a longlived, and currently active, tectonic plate boundary off the southern coast of Alaska.

An oceanic plate (currently the Pacific Plate), has been subducting northwestward beneath the continental crust of Alaska since early Jurassic time ( $\sim 200$ million years) (Trop and Ridgway, 2007; Amato and others, 2007). Voluminous magma was intruded into the overriding continental crust and partially expelled to the surface during several cycles of volcanic events lasting millions of years (Reed and
Lanphere, 1969; Wilson, 1985; Amato and others, 2007). A phase of arc magmatism is occurring today, resulting in the numerous volcanoes along the northwest side of Cook Inlet. This volcanic activity provides the heat source for potential geothermal fields, such as near Mount Spurr.

Compressive forces at the plate boundary have uplifted and exhumed much of this ancient intrusive arc system, exposing the granitic roots of the arc in what are now the southern Alaska Range and Talkeetna Mountains on the northwestern and northern margins of the Cook Inlet. To the southeast, massive amounts of sediment eroded off of the continental margin and deposited on the subducting oceanic plate have been scraped off and piled up since about 190 to 120 million years ago to form what are now the KenaiChugach Mountains (Connelly, 1978; Bradley and others, 2009). The strata composing the Kenai-Chugach Mountains were deposited at a location farther to the southeast than they occur today, and were transported northwestward along the now inactive Border Ranges fault to their current position by latest Cretaceous to early Paleocene time (Plafker and others, 1994).

The Cook Inlet forearc basin (sheet 2) resides between the topographic highs of the southern Alaska Range and Kenai-Chugach Mountains and maintains the highest energy resource potential in the region. The thick sedimentary rock package is bounded on the north and northwest by major fault systems that have been active at various times through the basin's history. The inactive Border Ranges fault separates the Cook Inlet basin to the northwest from the Kenai and Chugach mountains to the southeast. A system of faults defining the northwest boundary of the basin includes the Bruin Bay, Lake Clark, and Castle Mountain faults. Segments of each of these faults are believed to have been active within the last $\sim 500$ years to 1.8 million years. Beginning in Paleocene time, approximately 21,000 feet of sediment accumulated in the basin, sourced from erosion of the adjacent Alaska Range and Kenai-Chugach Mountains (Plafker and others, 1992, Conwell and others, 1982; Swenson, 2003; Haeussler and others, 2000). Nearly all of the hydrocarbons produced from the Cook Inlet were reservoired in these Tertiary rocks. An extension of the Cook Inlet basin exists northwest of the Castle Mountain - Lake Clark fault system in the Capps Glacier-Tyonek area (east of Mount Spurr). This fault-bounded depression, termed the Beluga basin (Hackett, 1977), is expressed as a gravity low and is filled by Eocene and younger nonmarine conglomerate, sandstone, mudstone, coal, tuff, and volcaniclastic deposits (Barnes, 1966; Magoon and others, 1976; Gillis and others, 2009; Finzel and others, 2009).

The adjacent Susitna lowland is a mostly fault-bounded, relatively shallow (Conwell and others, 1982) basin located at the northwestern end of the Cook Inlet basin and bordered by the Alaska Range to the west and north, and the Talkeetna Mountains to the east (sheet 2). The Susitna basin shares 
the younger stratigraphy of the Cook Inlet basin, including coal-bearing upper Tertiary strata. However, it appears to lack many of the same older stratigraphic units that provided the organic material to source the oil found in Cook Inlet. The timing of basin formation is uncertain, but has to be at least about 30 million years old, based on the oldest sediments (the Tyonek Formation) captured within the confines of the basin (Barnes, 1966). However, the mechanisms under which it was formed are uncertain.

The most prominent topographic feature in the Railbelt development region is the central Alaska Range, with its tallest peak reaching over 20,000 feet in elevation, making it the highest mountain range in North America. The central Alaska Range is bounded to the north by the active rightlateral strike-slip Denali Fault, and situated where the fault bends to the southwest. As the crust to the south of the fault moves around the bend against the backstopping crust to the north of the fault, it runs out of space and must shorten and thicken, thus creating topographic relief that is incised by erosion into rugged peaks. The initial phases of this uplift may have started as early 52 to 39 million years ago (Plafker and others, 1992), but significant uplift did not occur until as recently as 6 million years ago (Fitzgerald and others, 1995), making the central Alaska Range one of the youngest mountain ranges in Alaska. The uplift of the Alaska Range may represent far-field effects of the collision of the Yakutat microplate into, and continued underplating beneath continental Alaska at the subduction zone near Prince William Sound.

Tertiary age sediments deposited in the Nenana basin (sheet 2) record some of the history of Alaska Range uplift. Initial deposition into the basin was from source areas in the Yukon-Tanana highlands to the north (Wahrhaftig, 1969; Ridgway and others, 2007), in part from the northernmost Railbelt development area. As the Alaska Range became a more imposing topographic feature, detritus eroded from its flanks was carried by northward-flowing rivers into the Nenana basin (Wahrhaftig, 1969; Ridgway and others, 2007), and presumably southward-flowing rivers into the Cook Inlet and Susitna basins (Plafker and others, 1992). Currently, the Nenana basin is host to the only major coal mining operations in Alaska, and is considered a major underdeveloped coal province. Natural gas may also be important in the basin (see the following sections on Railbelt coal and petroleum resources, respectively).

\section{GEOLOGIC ENERGY RESOURCE POTENTIAL IN THE RAILBELT ENERGY REGION \\ Mineable coal resource potential}

The Railbelt development region contains the two of the largest coal provinces in Alaska (the Cook Inlet-Susitna and Nenana coal provinces; fig J2). Unlike other coal-rich regions, such as Alaska's remote western North Slope, the
Cook Inlet and Nenana coal provinces are located in close proximity to rail and major road transportation systems and within 75 miles of the two largest metropolitan areas in Alaska: Anchorage and Fairbanks (sheet 1). Commercial coal extraction has either occurred in the past, or is currently underway, for both provinces. Due to this mining activity, the geology of both regions is moderately well understood. The Cook Inlet - Susitna coal province comprises the Cook Inlet and Susitna lowland areas and is the largest of the Railbelt development region coal provinces. The Nenana coal province lies along the northern foothills of the central Alaska Range, mostly between the Parks and Richardson highways. The coals in these provinces are broadly similar in age and both formed in low energy environments. The following discussion proceeds from the largest geographic category (coal province), followed by summaries of individual coal fields and their constituent districts (fig. J3).

Cook Inlet-Susitna Coal Province. Coal-bearing rocks in the Cook Inlet-Susitna coal province are late Oligocene to early Pliocene in age and make up the Tyonek, Beluga, and Sterling formations of the Cook Inlet and Susitna basins. These strata are generally flat-lying or gently tilted except in the proximity of faults, where coal-bearing rocks are commonly tightly folded, steeply tilted, heavily sheared, and/ or abruptly truncated. Most bedrock located onshore within this coal province has been buried by more recent glacial and stream deposits, severely hampering the estimation of coal reserves. Coal-bearing rocks are generally exposed only along the faulted basin margins and associated folds, and it is only at these discontinuous exposures that surface geologic mapping can aid coal resource assessment. The remaining vast majority of the basin must be evaluated using more expensive subsurface methods such as exploratory drilling. The lenticular shape of individual coal beds limits their lateral continuity and further complicates extrapolating coal reserves over broad regions (Merritt, 1990).

Coal throughout the Cook Inlet - Susitna coal province is commonly low- to medium-grade subbituminous in rank, but ranges from high grade anthracite in areas of the Matanuska Valley to low grade lignite in the outlying Broad Pass coal field area (fig. J3; Apell, 1944; Merritt, 1985a). Total coal resources in the Cook Inlet - Susitna coal province are estimated at 1.5 trillion short tons of hypothetical coal, with identified resources estimated at 11 billion short tons (Merritt, 1990). A coal-potential map published by Merritt (1990) shows much of the uppermost Cook Inlet and areas rimming the Susitna lowland as having low to moderate coal potential. High potential areas include the Beluga region on the west side of upper Cook Inlet and the Matanuska Valley. Identified coal resources in the Beluga-Yentna region are estimated at 10 billion tons with total resources estimated at around 30 billion tons (McGee and O'Connor, 1975; Sanders, 1981). Individual coal fields within the Cook Inlet - Susitna province are ranked in decreasing size below, based on 


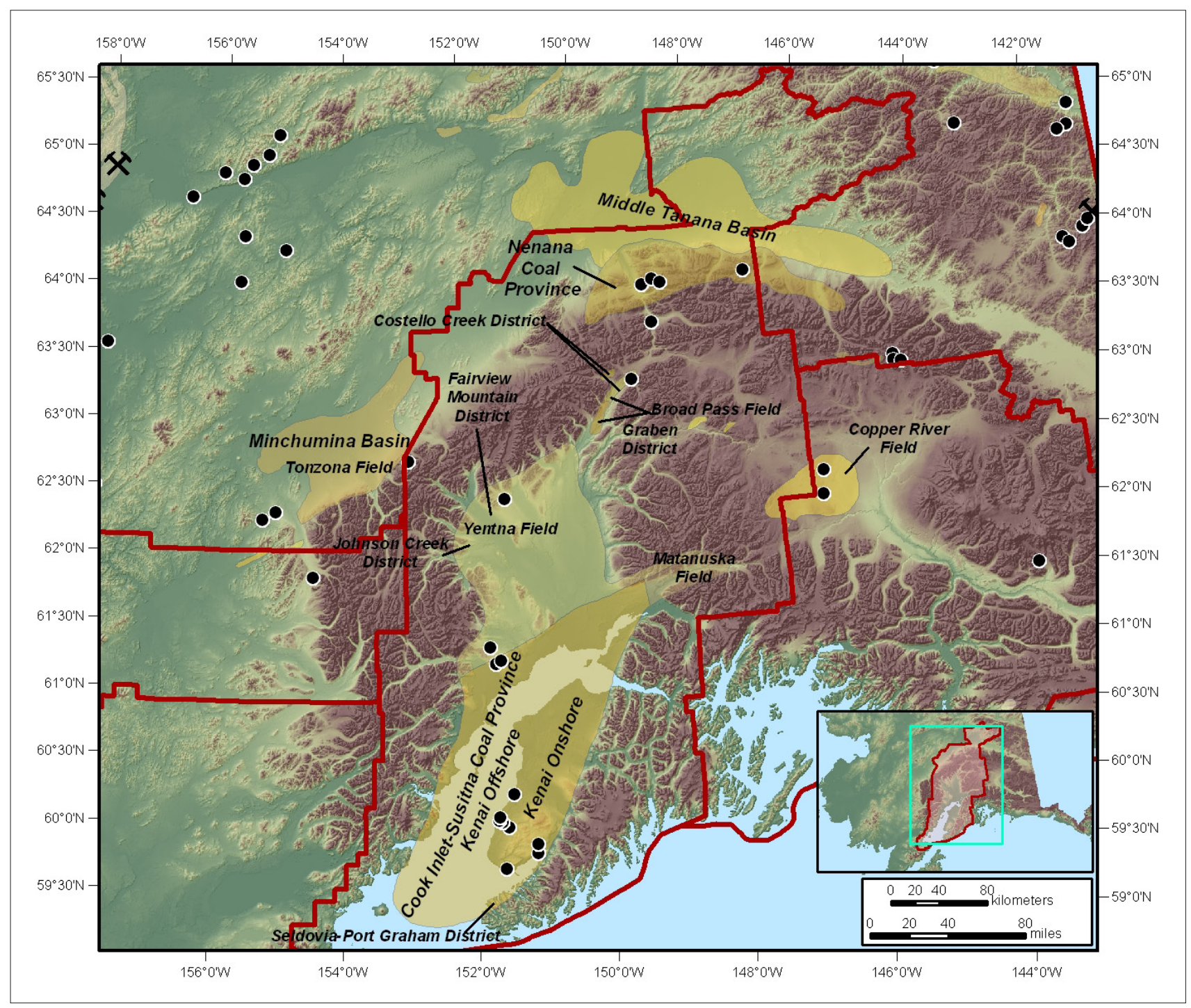

Figure J2. Location map of the Railbelt Energy Region, showing the Cook Inlet-Susitna and Nenana coal provinces (tan shaded areas). Black dots indicate selected reported coal occurrences.

estimates of indicated coal reserves. A short discussion of the coal potential of each field is also included.

Yentna Field. The Yentna field is located north of the Beluga and Susitna fields along the remote northwestern and northern side of the Susitna basin (fig. J3; sheet 2). Most of the Yentna field is separated from transportation infrastructure by the Kahiltna and Yentna rivers as well as 25 to 50 miles of low relief wetlands. The field is divided into the Canyon Creek, Johnson Creek, and Fairview Mountain districts (Merritt and Hawley, 1986). Coals from these districts are primarily derived from the Tyonek Formation, similar to the adjacent Beluga field. Few coal quality analyses have been published for the Yentna field, although measurements from coal throughout the Susitna lowland range from lignite to subbituminous $\mathrm{B}$, and are commonly subbituminous $\mathrm{C}$ in grade (Barnes, 1996). Mean heating value of coal in the Susitna lowland is around 8,000 Btu/lb as-received, and nearly $12,000 \mathrm{Btu} / \mathrm{lb}$ after drying and removal of ash (Merritt, 1990).

Coals in the Canyon Creek district generally range in thickness from 2 to 23 feet, most of which are exposed along Canyon Creek. Coal bed thicknesses may be over 55 feet-thick in some locations with few or no partings (Barnes, 1966). The district covers an area of less than $20 \mathrm{mi}^{2}$, and is surrounded by igneous and non coal-bearing Mesozoic rocks. Nevertheless, indicated coal reserves for the area are estimate at 100 million tons (Barnes, 1966). Intermittent coal exposures in the Johnson Creek District range in thickness from 3 to 24 feet, and indicated coal reserves in the Johnson Creek area are estimated at about 20 million tons based on reconnaissance field investigations by Barnes (1966). The thickest coals in the Yentna field are found in the Fairview 


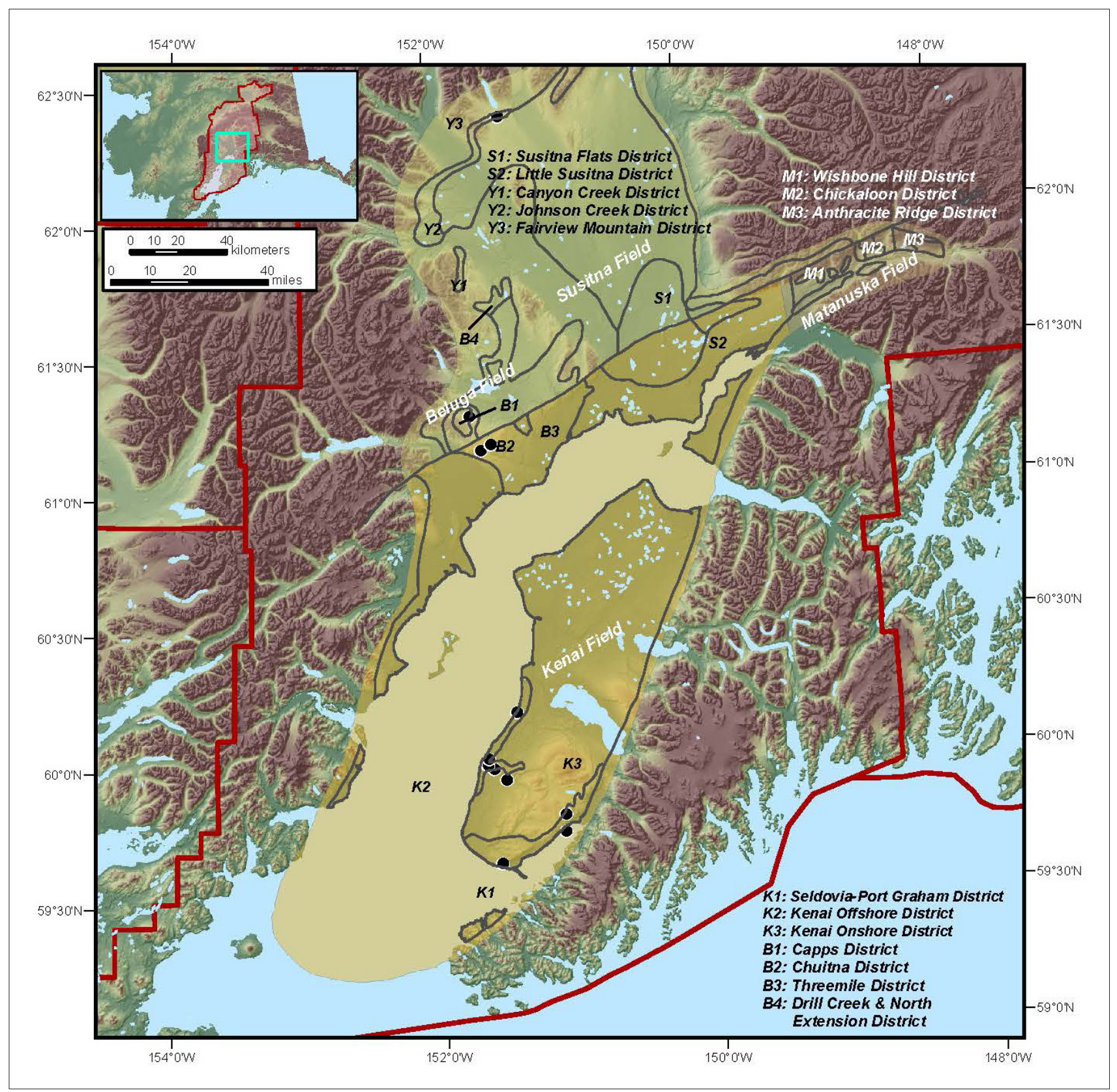

Figure J3. Map of the central Railbelt region, highlighting the coal fields and districts in the Susitna basin area. Black dots mark significant surface coal occurrences.

Mountain district near the northwestern margin of the Susitna basin, where coal beds are commonly 3 to 7 feet thick, with one bed reported to be 55 feet thick (Barnes, 1966). Indicated reserves in the Fairview Mountain district are based on reconnaissance field investigations and are estimated at 40 million tons (Barnes, 1966). Additional isolated exposures are found along the northern margin of the Susitna basin in the Peters Hills area where several low-grade coal beds are exposed along creek cuts. Cache Creek, northwest of Peters Hills has several beds of coal up to 2.5 feet thick (Barnes
1966). Twelve shallow boreholes were drilled to depths of less than $400 \mathrm{ft}$ in the Peters Creek area near the Parks Highway by Portland General Electric in 1976-; none of which penetrated more than two coal beds thicker than 1.5 to 4 feet (Merritt, 1990). Indicated coal reserves estimated by Barnes (1966) in the Peters Hills area are 4.5 million tons.

Overall, coal-bearing exposures in the Susitna lowland are limited to small isolated outcrops along the margins of the basin. Although the main part of the basin is masked by widespread glacial and alluvial deposits, the known rock 
types and age are very similar to the more extensive exposures in the Beluga-Chuitna areas (see below), suggesting much of the covered Susitna lowland could be underlain by coalbearing strata. Due to extensive cover and limited subsurface data, the Susitna lowland remains the least well understood region in the entire Cook Inlet coal provinces. Substantial subsurface exploration would be required to determine the volume and extent of potential coal resources.

Beluga Field. The Beluga field is perhaps the most studied field in the Cook Inlet coal province, and is the largest in terms of identified resources. It is located approximately 45 miles west of Anchorage on the western margin of the Cook Inlet and is divided into four main districts: the Capps district, the Chuitna district, the Threemile district, and Drill Creek and North Extension district (fig. J3; Merritt and Hawley, 1986). Although the Beluga field is not connected to commercial rail or highway infrastructure, it lies within 6 to 25 miles of port sites on Cook Inlet. The Beluga area has undergone considerable geologic and coal resource investigation since the mid1950s including regional gravity surveys, stratigraphic studies, and reconnaissance geologic mapping to constrain sedimentary basin geometry, stratigraphic architecture, and rock distribution (e.g. Grantz and others, 1963; Barnes, 1966; Adkison and others, 1975; Hackett, 1976, Flores and others, 1994; Flores and others, 1997). More focused studies include delineation of the resource and geotechnical characterization through publicly- and privately-funded exploratory drilling projects (e.g. Warfield, 1959; Chleborad and others, 1980, 1982; Odem, 1986; and Odem and others, 1986), and baseline studies of stream water and soil quality (e.g. Scully and others, 1980; Gough and Severson, 1983; Maurer, 1984, 1986 and 1987).

Coal in the Capps, Chuitna, and Drill Creek and North Extension districts are part of the late Oligocene to late Miocene age Tyonek Formation, whereas coal in the Threemile district are from the younger, Miocene age Beluga Formation. Coal in the Beluga field is generally of subbituminous grade with reported heating values ranging from about 7,500 to 8,500 Btu/lb. The measured ash content of these coals are moderately high and may require crushing and washing to increase its heating value (Merritt and Hawley, 1986; PacRim Coal, 2005).). The sulfur content is low; which reduces the risk of producing acid rain and acid mine drainage compared with many coal sources in the contiguous 48 states (Merritt and others 1986).

The Capps deposit south of Capps Glacier contains approximately 11 to 13 square $\mathrm{km}$ of mineable coal in two major beds. Dobey and McGee (1976) estimated that the Capps district contains nearly 550 million tons of identified mineable coal, although more conservative estimates from the Beluga Coal Company put the mineable reserves at approximately 200 million tons (Merritt, 1990). Merritt (1990) assigns high coal potential to the entire area south of
Capps Glacier northeastward to Coal Creek, and including Drill Creek.

The Chuitna district northeast of the Chuitna River is currently leased to PacRim Coal, who reports measured reserves of 809 million tons and additional indicated reserves of 254 million tons (PacRim Coal 2005). The proposed mine is in the advanced stages of the permitting process for both coal extraction and infrastructure development; if permitted, most of the coal extracted from the Chuitna district will likely be bound for foreign markets, although local in-state use would remain an option if a viable market were developed.

The Drill Creek and North Extension district is located east of Beluga Lake and west of Beluga Mountain. The total reserves for this district are uncertain although Dobey and McGee (1976) speculate that the region may contain more than one billion tons of coal. At Drill Creek, field observations (Barnes, 1966) and exploratory drilling (Warfield, 1959) identified coal beds greater than 10 feet thick totaling an estimated 64 million tons of coal. Coal reserves have not been estimated along the other major drainages, but are likely of minor significance because only 1 to 4 beds (each no greater than 4 feet thick) have been observed and the surrounding bedrock limits the lateral extent of the seams. The Threemile Creek district located along the Beluga River near the Cook Inlet coast is estimated to contain 150 million tons of coal (McGee, 1973). The Beluga Coal Company estimates 69 million tons of this coal is in beds approximately 10 feet-thick at a stripping ratio of 9:1 (Merritt, 1990).

The outlying areas of the Beluga field are less well understood than the defined districts. Dobey and McGee (1976) speculated that a 25 square-mile region between the Chuitna and Chakachatna rivers may contain 25 million tons of hypothetical coal. Part of this same region was deemed to have high coal potential by Merritt (1990). However, because of widespread glacial deposits that cover most of the underlying coal-bearing strata, additional exploratory drilling will be required to further delineate the presence and abundance of mineable coal resources in the outlying areas of the Beluga field.

Kenai Field. The Kenai field occupies nearly the entire lowland region of the Kenai Peninsula on the east side of upper Cook Inlet, including a small area near Seldovia (fig. J2 and sheet 2). The field encompasses, or lies within close proximity to, existing commercial highway and rail infrastructure and tidewater ports (Homer and Seward). The area is divided into three coal districts: Kenai onshore, Kenai offshore, and Port Graham (Merritt and Hawley, 1986). Coal from the Kenai onshore district occurs within the Middle Miocene to Early Pliocene age Beluga and Sterling formations. The coal beds are primarily visible in discontinuous coastal bluffs along the Kenai Lowland, from north of Clam Gulch on the western side of the Kenai Peninsula, to the Fox River, north of Kachemak Bay. Many coal seams are encountered in petroleum wells, indicating 
that coal-bearing strata underlie the entire Kenai Lowland. The grade of coal in the Kenai onshore district ranges from lignite to subbituminous, which is considered to have low to medium heating potential, with an average heating value of $7,700 \mathrm{Btu} / \mathrm{lb}$. The rank decreases in younger, shallower rocks. The coals have moderately high to high ash contents and may require crushing and washing to increase their heating value. The low measured sulfur content of the coal and overburden indicate a relatively low potential for producing acid rain or acidic contamination from mine waste materials.

The number and thickness of coal beds decreases northward along the Kenai Peninsula. Although Tertiary strata in the Kenai Lowland are typically flat lying or gently dipping, coal beds in the region are lenticular and locally offset by high-angle faults, making it difficult to extrapolate over lateral distances greater than $\sim 0.5 \mathrm{~km}$. The 1,100 square-mile area south of Tustumena Lake and the Kasilof River contains a total of 57.6 million tons of calculated measured, 347.2 million tons identified, and 41,550 million hypothetical tons of coal (Merritt and others 1987). Bedrock north of Tustumena Lake is obscured by thick Quaternary glacial deposits, but several thousand feet of coal-bearing deposits have been penetrated by wells in the Swanson River field as well as other exploration wells in the region. The main challenge to extraction of coal in the Kenai onshore district is the presence of glacial overburden that can be up to several hundred feet thick, particularly farther north along the peninsula. Because of the thick glacial deposits that cover the underlying coal-bearing bedrock, additional drilling will be required to further delineate the resource potential for much of the Kenai Peninsula. For further information, refer to Barnes and Cobb (1959) and Barnes (1967).

The Port Graham district, south of Kachemak Bay includes the site of the earliest coal mine in Alaska. The mine was operated by the Russians between 1855 and 1867, but was closed due to unprofitability (Stone, 1906). Estimates of the volume of coal in the Port Graham district have not been made, but recent field work in the area by the Alaska Department of Natural Resources suggests that coal is present only in thin (less than $20 \mathrm{~cm}$ thick), laterally discontinuous lignite seams.

An estimated 532 million short tons of coal from the Beluga and Tyonek formations of the Kenai Group are estimated to underlie much of Cook Inlet in the Kenai offshore district in beds more than 20-feet thick (McGee and O'Connor, 1975). Estimates were based on electric log interpretation from 47 exploratory and development wells on the west side of Cook Inlet. However at present, the coal is beyond extraction with current technology.

Matanuska Field. The Matanuska field encompasses approximately 195 square miles in the Matanuska Valley, located approximately 50 miles from downtown Anchorage (fig. J3 and sheet 2). The field is located directly adjacent to Alaska Highway 1 (Glenn Highway) at the upper end of the
Knik arm of the Cook Inlet. Thus, the Matanuska field is in close proximity to commercial road and rail infrastructure, a tidewater port, and the largest population center in the State of Alaska. The field was mined for coal from 1914 to 1968 , with the Premier Mine providing coal for local needs until 1982 (Merritt, 1988).

The field is divided into the Chickaloon, Wishbone hill, and Anthracite Ridge mining districts (Merritt and Hawley, 1986). Coal from each of these districts is derived from the Paleocene age Wishbone Formation. Coal grade in the district decreases southwestward from high grade semi-anthracite to anthracite grade at Anthracite Ridge to medium-grade bituminous coal in the Chickaloon district. Coal extracted from the Matanuska field has heating values that range from approximately 10,400 to $14,400 \mathrm{Btu} / \mathrm{lb}$ (Merritt, 1985a, Merritt and Hawley, 1986) and has relatively high ash and low sulfur contents (Merritt, 1986; Merritt and Hawley, 1986).

Coal overburden analyses yield low concentrations of pyritic sulfur, indicating low potential for acid mine drainage (Merritt, 1986). Resources for the entire field are estimated at 48.5 million short tons measured, 165 million short-tons identified, and hypothetical resources estimated up to 551 million short tons as of 1990 (Alaska Division of Geological \& Geophysical Surveys, 1990). Most of the mineable coal is concentrated in the Wishbone Hill and Chickaloon districts. Potential challenges to sustained coal extraction noted by Merritt (1986a) include significant faulting, sometimes with large magnitude offsets, coal beds that are laterally discontinuous, steeply-dipping coal beds that make strip mining difficult, and pinching and swelling of coal beds. Other potential complications include local degradation of coal quality from nearby igneous activity, the presence of locally abundant coal-bed methane that can add cost to underground mining operations, and the presence of impurities within the coal that would require crushing and washing to increase the energy value of the coal. Merritt (1988) also notes that the Matanuska field is unlikely to support large-scale mines with annual productions greater than one million tons per year. For a more thorough examination of the Matanuska field, refer to Merritt (1985).

Susitna Field. The Susitna field is bisected by the Castle Mountain fault (sheet 2), a significant structure that generally separates the field into two districts: the Susitna Flats to the north and the Little Susitna to the south (fig. J3). The Susitna Flats district lies within the Susitna basin between Mount Susitna and the Talkeetna Mountains. Coals in this district are part of the lower to middle Kenai Group (likely Tyonek Formation), and are known primarily through data from oil and gas exploration wells in the area (Conwell and others, 1982). The coal grade and resource potential for this area are uncertain. Merritt and Hawley (1986) assume mineable seams of sub-bituminous grade occur throughout much of the Susitna Flats district, although this may be in part due to their inclusion of locally exposed coal beds in the Houston 
area previously considered part of the Little Susitna district (Barnes and Sokol, 1959). Conversely, Merritt (1990) show a mostly low potential for mineable coal for the Susitna Flats district, highlighting the uncertainty of coal resources in the region.

The Little Susitna district has only been studied at a reconnaissance level through investigation of small, sparsely distributed coal outcrops and limited exploratory drilling (Barnes and Sokol, 1959). Coal in this district is hosted in the Oligocene to Miocene age Tyonek Formation and is subbituminous grade. Heating values determined from only a few samples range from about 8,500 to $13,000 \mathrm{Btu} / \mathrm{lb}$. Coal beds are thin, typically less than 4 feet-thick with abundant clayey partings, and are often widely spaced and laterally discontinuous. A poorly defined potential reserve in the Little Susitna district is estimated by May and Warfield (1957) to be 14.7 million tons.

Broad Pass Field. The Broad Pass field is located near Broad Pass, south of Cantwell, and is divided into the Graben and Costello Creek districts (fig. J3; Merritt and Hawley, 1986). The relationship between coal-bearing strata in the Broad Pass area and those in the Cook Inlet-Susitna and Nenana areas is uncertain, but the Broad Pass coal is believed to also be Tertiary, perhaps Pliocene in age (Merritt and Hawley, 1986). Two to 10 feet-thick lignite beds in the Graben district have heating values that range from about 6,600 to $7,400 \mathrm{Btu} / \mathrm{lb}$ and high ash contents from about 9 to $32 \%$ (Hopkins 1951). The lignite seams contain low sulfur values ranging from 0.2 to 0.4 percent (Merritt and Hawley, 1986). Coal in the Costello Creek district is slightly higher in grade at subbituminous A (Wahrhaftig, 1944).

Estimated coal reserves in the Graben district are based on limited trenching and few exposures, thus the conservative estimate of 13.5 million tons of lignite is poorly constrained (Hopkins, 1951). Indicated coal reserves in the Costello district, including the long-closed Dunkel mine, are 353,000 tons (Wahrhaftig, 1944). Despite easy accessibility of the Broad Pass field by rail and road systems, the low grade of coal in this field probably does not warrant further consideration as an energy alternative for local communities. However, the region is actively being explored for gold and related minerals and if development occurred, these low grade coals may warrant further exploration as a potential energy source.

Nenana Coal Province. Coal-bearing strata in the Nenana coal province occur within the Nenana Basin in a series of discontinuous sub-basins arrayed along the northern foothills of the central Alaska Range (fig $\mathrm{J} 2$ and sheet 2). These coal-bearing rocks extend from the Jarvis Creek coal field in the Yukon-Koyukuk/upper Tanana energy region (see chapter L) at their eastern extent, approximately 200 miles southwestward to about the Kantishna Hills in a belt that is up to 30 miles wide (Merritt, 1985b). Southwest of the Kantishna Hills the belt continues discontinuously to at least the Cheeneetnuk River area, southwest of Farewell, in the Lower YukonKuskokwim energy region. Coal-bearing strata are found within five geologic formations of late Oligocene to late Miocene-age; from oldest to youngest, these include the Healy Creek, Sanctuary, Suntrana, Lignite Creek, and Grubstake formations (Wahrhaftig and others, 1969; Wolfe and Toshimasa, 1980). Of the five formations, the Suntrana, Healy Creek, and Lignite formations contain significant coal reserves. The coal is typically subbituminous $\mathrm{B}$ and $\mathrm{C}$ in rank, with heating values ranging from 8,000 to 9,500 Btu. They have medium ash contents and very low sulfur contents. Thicknesses of individual coal beds range from 10 to 60 feet (Merritt, 1985). Identified coal resources of the Nenana coal province are estimated at 7 billion short tons, and inferred coal resources throughout the province are estimated at about 10 billion short tons, for a total of 17 billion potential tons (Sanders, 1981). The geology and coal resources of the two largest fields (Lignite Creek and Healy Creek) are well characterized, however comparably little has been published about the remaining smaller fields.

Ten coal fields are recognized within the Nenana Coal Province, although only seven occur within the Railbelt Development Region. The Jarvis Creek, West Delta, and East Delta fields are considered part of the Nenana coal province, but are located to the east in the Yukon-Koyokuk/upper Tanana development region (chapter $\mathrm{L}$ ). The seven individual fields within the Railbelt region are discussed below in order of decreasing size based on estimated reserves within 500 feet of the surface and coal bed thicknesses of at least 29 inches or greater (Merritt, 1985b).

Lignite Creek field. Coal in the Lignite Creek field is discontinuously exposed in outcrop over an area of approximately 100 square miles, extending from the Nenana River and Parks Highway near Healy in the west, to the headwaters of Tatlanika Creek in the east. Coal beds in this field can achieve 60 feet in thickness, and some seams are laterally continuous for up to ten miles. Mineable reserves at a stripping ratio of $4.25: 1$ were estimated at 150 million tons in the mid 1970's for the Lignite Creek field (Renshaw, 1977). Merritt (1985b) estimates that 936 million short tons of potentially mineable coal with bed thicknesses of at least 29 inches exists in the field within 500 feet of the surface. The Lignite Creek field has produced 50 million tons of coal to date and the Usibelli Coal Mine currently produces an average of 1.5 million tons of coal per year from this field (Usibelli Coal Mine, Inc., 2009).

Healy Creek field. The Healy Creek field is located directly south of the Lignite Creek field and encompasses less than 25 square miles from the Nenana River and Parks Highway in the west to the middle of the Healy Creek drainage to the east. The field includes a similar stratigraphic succession as recognized elsewhere in outcrop along the southern margin of the Nenana Basin. The Usibelli Coal 
Company (and others before them) mined coal from the Healy Creek field over a thirty-year period from 1944 to 1972 . The field now is largely depleted of easily accessible deposits, but may still have as much as 250 million mineable short tons of coal using more expensive mining methods (Merritt, 1985).

Western Nenana field. The Western Nenana field spans the Parks Highway between the Nenana and Sanctuary Rivers, and lies in part in Denali National Park. Estimated coal resources in this area are 250 million tons (Wahrhaftig and others, 1951) from the lower Nenana Basin coal-bearing stratigraphy, with an estimated volume of potentially mineable coals within 500 feet of the surface of 80 million short tons (Merritt, 1985).

Tatlanika field. Coal-bearing strata of the Tatlanika field are exposed over an area of approximately a 120 square miles, and is located about 12 miles east of Liberty Bell Mine and 25 miles east of the Parks Highway, extending from Buzzard Creek in the west to Grubstake, Roosevelt, and Hearst creeks on the east. Merritt (1985) estimates that 77 million short tons of potentially mineable coal with bed thicknesses of at least 29 inches exist in the field within 500 feet of the surface from the Healy Creek through Grubstake formations.

Wood River field. Coals of the Wood River field occur in an area of less than 40 square miles located on the northwest flank of Mystic Mountain about 40 miles east of the Parks Highway. At least 16 significantly thick coals occur within the field and span the entire stratigraphic range of coal-bearing units within the Nenana Province. The field has an estimated 80 million short tons of potentially mineable coal within 500 feet of the surface (Merritt, 1985).

Rex Creek field. Coal-bearing strata of the Rex Creek field occupy 25 square miles located about 15 miles east of the Parks Highway in an area crossed by Rex Creek located east of Rex Dome and west of Iron Creek. At least 15 million short tons of potentially mineable coal occur in the Healy Creek, Sanctuary, and Suntrana formations (Merritt, 1985).

Mystic Creek field. The Mystic Creek field is located east of the Wood River between Keevy Peak to the southwest and Mystic Peak to the northeast, about 35 miles east of the Parks Highway. At least 10 coal beds up to 15 feet thick are present in outcrop over a 20 square mile area. The field has an estimated 20 million short tons of potentially mineable coal from the Healy Creek Formation and other undifferentiated strata (Merritt, 1985).

\section{Conventional oil and gas resource potential}

As explained in the discussion of requirements for exploitable oil and gas resources (Chapter A), functioning petroleum systems occur in thick sedimentary basins, and require three basic elements: effective source rocks, reservoirs, and traps. Each of the elements must be in existence and connected at the time hydrocarbons are generated. This section provides an overview of the various basins in the Railbelt region then considers each of the necessary elements of petroleum systems in turn to evaluate the role conventional oil and gas resources may play in supplying rural energy to Alaska's Railbelt energy region.

Overview of sedimentary basins. The Railbelt region encompasses several main Tertiary age sedimentary basins, including the Cook Inlet, Susitna, the eastern part of the greater Nenana basin, and the northeast part of the Minchumina basin (sheet 2; Kirschner, 1988). The Nenana basin is also known as the Tanana basin (e.g. Trop and Ridgway, 2007) or Middle Tanana basin (Ehm, 1983; Stanley and others, 1990).

The Cook Inlet basin contrasts with the other Railbelt basins in many respects, including areal extent, thickness, tectonic setting, and petroleum productivity. Situated above southern Alaska's subduction zone, the Cook Inlet is a forearc basin filled by sediment eroded from the Aleutian Range and southern Alaska Range magmatic arc to the west, the central Alaska Range and Talkeetna Mountains to the north, and the Chugach-Kenai Mountains accretionary prism to the southeast. Most exploration in the Cook Inlet basin has occurred on state-managed land, whereas extensive private and federally protected areas are either lightly explored or closed to exploration. The vast majority of hydrocarbons produced from basin thus far were found in Tertiary nonmarine strata deposited in alluvial fans, river channels, floodplains, lakes, and coal swamps. These units overlie older Mesozoic formations of mixed marine and nonmarine origin. Proven petroleum systems in the Cook Inlet basin have supplied local and export markets more than 1.3 billion barrels of oil and nearly 7.75 trillion cubic feet of gas since the late 1950s (Alaska Division of Oil and Gas, 2007; Hartz and others, 2009). Most of this success has resulted from targeted exploration of large anticlinal structures that are readily apparent on seismic data. Although many of these structures have been drilled and tested, these folds continue to attract exploration and active industry leases suggest the potential for future discoveries. Significant additional hydrocarbons are likely also housed in stratigraphic traps, although this type of accumulation is subtle and has only been lightly explored.

The Cook Inlet basin has witnessed declining production from existing fields drawing attention to its role in meeting south-central Alaska's future energy needs. Recent studies undertaken by the Alaska Division of Oil and Gas (Hartz and others, 2009) suggest there may be significant volumes of recoverable gas in parts of Cook Inlet's complex fluvial reservoirs that are not tapped effectively by existing wells. It may be feasible to recover some of this nonproducing gas through more complete field development projects in the near term. Furthermore, the State of Alaska is attempting to incentivize new exploration activity via major tax credits.

Exploitable petroleum systems may exist in the Susitna, Nenana, and Minchumina basins, although limited exploration has not yielded oil or gas production. Both the 
Susitna and Nenana basins are candidates for exploration under active State-issued exploration licenses.

The Susitna basin is regarded as a northern extension of the Cook Inlet basin, separated by the Castle Mountain - Lake Clark fault, one of several arcuate strike-slip fault systems that traverse south-central Alaska. Nonmarine Cenozoic sedimentary strata reach a thickness of at least $3.7 \mathrm{~km}$ in the axis of the Susitna basin, indicating the region witnessed much less subsidence than the Cook Inlet basin. The origin and tectonic history of the Susitna basin is poorly known; subsidence may reflect activity on steep basin-bounding faults (Ehm, 1983; Kirschner, 1988), or deeper processes associated with a colliding crustal fragment to the southeast (Finzel and others, 2011). Miocene and younger basin-filling units are recognized in Susitna lowland outcrops (Reed and Nelson, 1980; Dickinson, 1995), and Paleocene to Eocene age strata are believed to be penetrated in the deeper exploration wells (R. Stanley, USGS, written communication). Two wells were drilled in the Susitna basin west of the Susitna River, in 1964 and 1980 . Some $3,470 \mathrm{~km}^{2}$ of the basin, including its deepest parts, are eligible for new drilling within the two adjacent exploration licenses issued on State lands in 2003.

The Nenana and Minchumina interior basins lie at the north end of the Railbelt region, along the northern flank of the Alaska Range. The Nenana basin is bound to the north by the Yukon-Tanana uplands and the Minchumina basin occupies the lowlands between two range-bounding fault systems, the Farewell fault zone to the south and Iditarod fault zone to the north. Only the shallow southern and eastern part of the Nenana basin and the northeastern part of the Minchumina basin fall within the Railbelt energy region; the remainders of both basins are located in the Yukon-Koyukuk/ Upper Tanana energy region.

The Nenana basin contains Eocene and younger nonmarine deposits overlying metamorphic basement. The coal-bearing Usibelli Group and Nenana Gravel are exposed in the northern foothills of the Alaska Range (in an area sometimes referred to as the Healy basin). However, broad, low-lying areas of the greater basin are covered by Quaternary surficial deposits, limiting direct examination of the stratigraphy. The source of these sediments is interpreted to change over time; the older Usibelli Group was deposited by streams that flowed southward from the ancient YukonTanana uplands, whereas the Nenana Gravel was deposited by streams flowing north out of the Alaska Range following major uplift in late Cenozoic time (e.g., Stevens, 1971; Buffler and Triplehorn, 1976; Wahrhaftig, 1987; Stanley and others, 1992; Trop and Ridgway, 2007).

The age of sediments deposited in the Minchumina basin is poorly constrained. Upper Cenozoic (Neogene) gravels are locally exposed at its eastern periphery, and their equivalents probably extend beneath surficial cover throughout most of the basin. Lower Cenozoic (Paleogene) nonmarine sedimentary strata are inferred to be present in the subsurface near the Farewell fault zone (Kirschner, 1988), but they do not appear in outcrop (Wilson and others, 1998).

Constraints on the thickness of the Nenana and Minchumina basins come from integrating regional gravity and local seismic data with the observed depth to basement in the two wells with publicly available data: the Union Nenana 1 (located in the adjoining Yukon-Koyukuk/ Upper Tanana energy region) and the ARCO Totek Hills 1 (located just inside the boundary of the Railbelt energy region). Both wells were drilled at the edge of the main fault-bounded Nenana basin, and penetrated basement at depths less than $1.1 \mathrm{~km}$. A third well was drilled in the basin in 2009 (Nunivak 1) and although most of the data remain confidential, it is known to have targeted a prospect at approximately 3.2 to $3.3 \mathrm{~km}$ depth, located between even deeper fault bounded depressions containing up to 4-6 km of sedimentary strata (Petroleum News, 2009; Petrotechnical Resources and Doyon, Ltd., undated; Frost, 2003; Grether and Morgan, 1988). This sector of the Nenana basin is sufficiently deep to host an effective conventional petroleum system based on thermogenic-sourced hydrocarbons. This part of the basin is mostly encompassed by the exploration license issued in 2002, and is located outside the Railbelt energy region.

No oil or gas wells have been drilled in the Minchumina basin. Gravity data indicate basement lies at shallow depths (a kilometer or less) across much of the basin, although deeper fault-bounded depressions appear to be present in localized areas and are presumably filled with nonmarine Tertiary strata. (Meyer and Krouskop, 1986; Kirschner, 1988; Meyer, 2008). Most of the Minchumina basin that falls within the Railbelt energy region is encompassed by Denali National Park and Preserve, and is unavailable for energy resource development.

Source rocks. Natural seeps of oil and gas in the Iniskin Bay-Chinitna Bay area on the northwest side of Cook Inlet are associated with outcrops of the Middle and Upper Jurassic formations, and were reportedly known in Russian colonial times (Martin, 1905; Martin, 1921; Detterman and Hartsock, 1966). Modern geochemical analysis suggest that nearly all the oil (and associated gas) produced from upper Cook Inlet oil fields, is sourced from thermogenic maturation of thick, widespread organic rich marine siltstone and shale of the Middle Jurassic Tuxedni Formation (Magoon and Anders, 1992). In contrast, most of the natural gas fields in Cook Inlet have a different source. This gas is biogenic in origin, sourced by low-temperature bacterial decay of the abundant coals present in Cenozoic formations (Claypool and others, 1980). A critical factor in developing conventionally exploitable biogenic gas accumulations is late-stage uplift, which lowers the subsurface pore pressure, allowing the dissolved gas to desorb from the coal so it can coalesce as a free gas phase and migrate into reservoir pore space. Most of the Cook Inlet gas fields probably owe their existence to significant uplift 
and erosion during the last few million years of late Cenozoic time (Haeussler and others, 2000; Swenson, 2003).

The trend of the Jurassic forearc basin suggests the Susitna Basin is unlikely to be underlain by the same Jurassic oil-prone source rocks that are present beneath the Cook Inlet Basin. The thickness of Cenozoic sediments in most of the Susitna basin appears to be insufficient to have generated significant thermogenic hydrocarbons. However, the abundance of coal in the basin suggests favorable conditions for biogenic gas generation. Little is known of the uplift history of the basin, but similar to Cook Inlet, it may have undergone late-stage uplift freeing biogenic gas.

Available data indicate the Nenana and Minchumina basins are exclusively filled by nonmarine strata and are likely to contain mostly gas-prone coaly source rocks. However, limited publicly available information from the Totek Hills \#1 well and outcrops near Healy suggests there may be intervals with potential to generate petroleum liquids (Grether and Morgan, 1988; Stanley and others, 1990). The Nenana basin's deepest portions might be mature for thermogenic hydrocarbon generation, and abundant coals allow for the possibility that biogenic gas could occur in shallower portions of the Nenana and northeastern Minchumina basins.

Reservoir rocks. Cenozoic sandstones in Cook Inlet exhibit variable reservoir quality depending on their grain size, composition and total depth of burial (Hickey and others, 2007). The younger strata within the basin (Miocene and Pliocene) are often only lightly cemented and yield very high porosity and permeability values (Helmold and others, 2011). Reservoir quality data for the Susitna, Nenana and Minchumina basins is very limited or absent. However, nonmarine sandstones in these basins may have derived from broadly similar source terrains as Cook Inlet and thus potentially share similarly favorable reservoir quality. Sandstone reservoirs in these nonmarine basins often exhibit significant lateral and vertical variability reflecting the positions of ancient river channel deposits. The ultimate complexity of this type of reservoir will determine the size of any possible hydrocarbon accumulations.

Traps. The active tectonic setting of southern and central Alaska ensures the presence of numerous structural and stratigraphic trapping configurations. All major producing oil and gas accumulations in the Cook Inlet basin occur in anticlinal closures, many of which contain stacked successions of reservoir sandstones and sealing mudstones. This reliable trapping mechanism is likely in the other Railbelt basins, although insufficient subsurface mapping is available to evaluate the style folding. The elements necessary for fault-bounded traps and stratigraphic traps are probably also present in the energy region, and may be effectively sealed. Stratigraphic traps are likely to be subtle features and represent a challenging target for future exploration.
Summary of conventional oil and gas resource potential. The Cook Inlet Basin has a long history as the hub of oil and gas exploration and production within the Railbelt region. Although many producing assets in Cook Inlet are mature, significant potential remains in under-developed reservoirs in producing fields and undrilled prospects. The most recent USGS assessment of the region estimated a mean value of 599 million barrels of oil and 13.7 trillion cubic feet of natural remain to be discovered in Cook Inlet (Stanley and others, 2011). The Susitna and Nenana basins have no proven economic oil and gas resources. However, these basins have only been lightly explored and the limited available geologic information suggest there is some gas resource potential. Additional data and exploratory drilling will be needed before it will be possible to predict how much, if any, of the Railbelt's long-term energy demand these basins can be supply. The northeast part of the Minchumina basin that falls within the Railbelt energy region has very minor gas resource potential; encompassed by Denali National Park, it is not a candidate for energy development.

\section{Unconventional oil and gas resource potential}

Coalbed methane. The Railbelt energy region includes two large coal provinces with potential for significant volumes of coalbed methane: the Cook Inlet province and Nenana province. The overall coalbed methane potential for the Cook Inlet coal province is high as evidenced by a recent USGS assessment estimating a mean value of more than 4.5 trillion cubic feet of coalbed gas remains undiscovered in the greater Cook Inlet area (Stanley and others, 2011). Although this number evaluates technically recoverable resources, it includes offshore regions that are unlikely to be economically developed. Nevertheless, the abundance of Cenozoic coal beds in the Cook Inlet Basin and available geologic data are consistent with a very large gas resource present within shallow subsurface coal seams in the region. The resource potential is greatest in regions with higher rank coals, such as the Matanuska coalfield that contains bituminous and semi-anthracite coals. The Kenai, Broad Pass, and Beluga coalfields possess lower rank coals, some of which may not have sufficiently developed natural fractures (cleats) to permit gas flow. Desorption analyses of cores and cuttings indicate an average gas content of $230 \mathrm{scf} /$ ton (standard cubic feet per ton) for bituminous coals and $80 \mathrm{scf} /$ ton for subbituminous coals. Isotherms constructed for samples of both coal ranks suggest that bituminous coals are saturated with respect to methane, whereas subbituminous coals are locally unsaturated (Flores and others, 2004). Coals range in thickness from 2 to $50 \mathrm{ft}(0.6$ to $15 \mathrm{~m})$ and in gas content from 50 to $250 \mathrm{scf} /$ ton. They occur in the Miocene-Oligocene fluvial deposits of the Kenai Group (Montgomery and others, 2003) and are the probable source of more than 7 trillion cubic feet of biogenic gas that has been produced from conventional 
sandstone reservoirs in the basin. Many of the coal beds in the Tyonek Formation in the upper Cook Inlet Basin contain coalbed methane (Smith, 1995). Gas content ranges from 63 $\mathrm{ft}^{3}$ per short ton at standard temperature and pressure (STP) for coal beds at a shallow depth of $500 \mathrm{ft}$ to $245 \mathrm{ft}^{3}$ per short ton at standard temperature and pressure for coal beds at a depth of 1,200 ft (Flores and others, 2004).

Coal beds of the upper Tyonek and lower Beluga Formations contain the best coalbed methane potential on the Kenai Peninsula, especially in reservoirs less than 6,000 $\mathrm{ft}$ deep. They occur at shallow depths along the western coast of the southern Kenai Peninsula and are readily accessible. Coals in the Tyonek and Beluga Formations contain as much as 2.5 percent by volume of coalbed methane (Flores and others, 2004). Based on borehole data, coals in the upper part of the Tyonek Formation contain by far the most coalbed methane resources. Coals in the lower part of the Beluga Formation contain moderate amounts of coalbed methane resources and coals of the Sterling Formation contain very low coalbed methane concentrations. The difference in the coalbed methane content between the Beluga and Sterling coals may be related to the variation in their rank, beds in the Sterling Formation being mainly lignite and those in the Tyonek and Beluga Formations being mainly subbituminous (Barnes and Cobb, 1959).

Attempts to develop Tyonek coal beds by energy companies (Union and Ocean Energy) in the Wasilla area were adversely affected by the co-production of water. Large amounts of groundwater were encountered, which posed production problems in separating methane from produced water, as well as water-disposal problems by re-injection. Other targets for coalbed methane development in the Upper Cook Inlet are in the Tyonek area where the coal beds in the Tyonek Formation are as much as $50 \mathrm{ft}$ thick occur at shallow depths of less than $2,000 \mathrm{ft}$ (Flores and others, 2004). The existing infrastructure of petroleum development in the area, including pipelines, would be an additional aid to the development of coalbed methane. Based on gas contents of the Tyonek coals in the upper Cook Inlet which range from 63-245 scf/t at STP, the in-place methane resources in that part of the basin may be significant.

The coalbed methane potential in the Nenana coal province is lower than for the Cook Inlet coal province. The coal beds in this coal province are mainly subbituminous, range from 50 to $66 \mathrm{ft}$ (15 to $20 \mathrm{~m}$ ) in thickness, and occur to depths of 3,000 ft $(910 \mathrm{~m})$. Exploration targets for coalbed methane are along the axes of large synclinal basins such as the Healy Creek and Lignite Creek Basins. Most of the coals in the Healy Creek and Suntrana Formations are thick (up to $65 \mathrm{ft}$ ) and are at shallow depths of 1,000-to 3,000-ft (Wahrhaftig and others, 1994). Coals in the Healy Creek, Suntrana, and Lignite Creek fields are mainly of subbituminous rank, with lesser lignite, and generally increase in grade to the south-southeast, toward the Alaska Range. Outcrop and surface-projected vitrinite values of the coal-bearing Usibelli Group in the Central Alaska-Nenana coal province range from 0.21 to 0.48 percent, which corresponds to lignite to subbituminous $\mathrm{C}$ coal ranks (Flores and others, 2004).

Tight gas sands. In the Railbelt energy region, the Cook Inlet basin has the most potential for extensive tight gas resources. Potential exists in both Tertiary and Mesozoic age strata, although the greater age and depth of burial of the Mesozoic section suggests increased potential for tight gas sands. The vast majority of Sterling, Beluga and Tyonek sandstones in upper Cook Inlet are conventional oil and gas reservoirs with typical porosities greater than $20 \%$ and permeabilities greater than 10 md (Helmold and others, 2011). West Foreland sandstones have undergone more compaction and cementation than the younger Tertiary reservoirs and, where sufficiently buried, may act as tight gas sands.

Many of the Mesozoic sandstones in the Cook Inlet region, in particular the Naknek Formation and Tuxedni Group have been relatively deeply buried and have undergone significant compaction and cementation (Helmold and others, 2011). Porosities are typically less than $10 \%$ and permeabilities less than $0.1 \mathrm{md}$ are routinely recorded. These older, more lithified sandstones have potential as tight gas sands particularly those subjected to cataclastic deformation in addition to burial diagenesis. Extensive regional fractures have been observed in outcrops of some of the Mesozoic sandstones, particularly the Naknek formation in the lower Cook Inlet basin. Preliminary measurements of these fractures suggest they may have formed prior to Cenozoic folding and hydrocarbon migration, a scenario that improves the probability of a fracture-based unconventional petroleum system in Cook Inlet (Gillis and Wartes, 2011).

Shale gas. One of the primary requirements for shale gas is an organic-rich source rock present in the thermogenic gas window that is sufficiently brittle to host a natural fracture system (see chapter A). In Cook Inlet the most promising area for thermogenic gas charge is the widespread marine siltstone and shale of the Middle Jurassic Tuxedni Formation. Although the Mesozoic source rocks appear mostly oil prone there is some potential for thermogenic gas generation, as evidenced by the recent USGS assessment estimates a mean value of 637 billion cubic feet of shale gas remain to be discovered in the basin (Stanley and others, 2011). The general lack of thermogenic gas recognized in nonmarine Tertiary rocks suggests shale gas potential is low. This likely reflects a combination of factors, including insufficient maturity in parts of the basin and a lack of laterally continuous gas-prone mudstone intervals.

As noted above, the Susitna and Beluga basins probably have no underlying Mesozoic oil or gas source rocks and therefore have little potential for shale gas. In addition, these basins are not deep enough to have reached the thermal maturity necessary for generating appreciable thermogenic gas. 
Nonmarine strata filling the Nenana and Minchumina basins are likely to contain mostly gas-prone coaly source rocks and may have limited potential for shale gas. It is uncertain whether these basins are hot and deep enough to generate significant quantities of thermogenic gas to sustain an economic shale-gas reservoir. Gravity data for both basins suggests that only small areas are deep enough for thermogenic gas, which significantly reduces the aerial extent of potential shale gas source rocks.

Gas hydrates. The main occurrences of gas hydrates in nature are in modern marine sediments and in arctic regions with well developed, continuous permafrost. Permafrost is not well developed in the Railbelt Energy Region and, where locally present, is discontinuous. Consequently the potential for economic concentrations of gas hydrates in the region is low.

\section{Geothermal resource potential}

The Railbelt Energy Region has only one recognized thermal spring and several fumarole fields (sheet 2; Motyka and others, 1983). However, the proximity of these potential resources to population centers and infrastructure has led to more exploration and development activity than other regions in the state, including three geothermal lease sales in the Mount Spurr area and a successful geothermal development project at Chena Hot Springs Resort. Geothermal production of electricity at Chena hot springs has attracted attention because of the slightly lower temperature of the resource than most other binary power plants. Historically, ten Chena thermal springs, resulting from circulation of meteoric waters along fractures and faults in intrusive and metamorphic rock units, produced a combined flow rate of $225 \mathrm{gal} / \mathrm{min}$ at a maximum discharge temperature of $145^{\circ} \mathrm{F}\left(63^{\circ} \mathrm{C}\right)$ (Motyka and others, 1983). Geothermometry estimated a reservoir temperature between $266^{\circ} \mathrm{F}-293^{\circ} \mathrm{F}\left(130^{\circ} \mathrm{C}-145^{\circ} \mathrm{C}\right)$ (Motyka and others, 1983). More recently, nearly 20 wells have been drilled at Chena Hot Springs to depths of 100-1000 ft to facilitate geothermal energy production and to measure temperatures (hottest being $176.5^{\circ} \mathrm{F}\left[80.3^{\circ} \mathrm{C}\right]$ ) and pressures of the shallow geothermal system (Chena Hot Springs Resort, 2009b).

There are at least six mapped fumarole fields situated in close proximity to the chain of volcanoes running down the west side of Cook Inlet from Mount Spurr to southwest of Mount Douglas (Motyka and others, 1983). Mount Spurr's potential for geothermal development has received the most interest over the past 26 years (Wescott and others, 1985 ) and as a result there have been three State lease sales conducted in 1983, 1986, and 2008. The first two leases attracted bids on three tracts, all of which have expired or been terminated. During the most recent sale, Ormat Technologies, Inc. successfully acquired 15 leases on the south flank of the volcano. With matching State funds, Ormat has recently conducted an exploration program, including airborne geophysics and drilling. In 2011, well difficulties prevented drilling to the planned depth; preliminary data indicate a viable geothermal resource was not identified, although water chemistry and alteration suggest the well may have been peripheral to a hydrothermal system (B. Martini, Ormat, oral comm., 2011). If future drilling is attempted and proves successful, the project would require approximately 40 miles of transmission line to tie into the Beluga power plant. In addition to geologic and economic hurdles, any successful development project would need to address the risk associated with infrastructure on the flanks of an active volcano.

The active Augustine volcano in central Cook Inlet has been proposed for state geothermal leasing as recently as 2008. Despite its proximity to population centers on the Kenai Peninsula, leasing has not moved forward, principally due to the lack of any identified hydrothermal resource and concerns over natural hazard risks associated with any infrastructure on the volcanic island.

Four wells drilled in the lower Susitna basin in the Willow-Big Lake area registered geothermal gradients of $2.25^{\circ} \mathrm{F}-6.75^{\circ} \mathrm{F} / 100$ feet $\left(4.1^{\circ} \mathrm{C}-12.3^{\circ} \mathrm{C} / 100\right.$ meters $)$ in thick Tertiary successions overlying granitic basement rocks (Motyka and others, 1983). One interpretation for this unexpectedly high thermal gradient is a shallow, discontinuous, low-grade geothermal reservoir up to 40 square miles (104 square kilometers) in area (Turner and Wescott, 1982). However, recent re-evaluation of key well data by geologists at DGGS concluded the anomalous bottom hole temperature is most likely a drilling artifact or otherwise erroneous (C. Nye, DGGS, written commun., 2011).

\section{RECOMMENDATIONS \\ Conventional oil and gas resource recommendations}

The Cook Inlet basin has been producing oil and gas for more than 50 years, but there is reason to believe that with continuing investment in second- and third-cycle development projects, several of its largest gas fields may be able to meet regional demand for the immediate and mid-term future. Renewed exploration of undeveloped prospects with known or inferred bypassed gas shows, and focused exploration for stratigraphically trapped gas may yield discoveries that will contribute to meeting long-term demand. This next generation of exploration will require an improved understanding of the stratigraphic architecture and distribution of reservoir quality within the Cook Inlet basin. Continued efforts by geologists at the Department of Natural Resources to publish results of detailed field and subsurface investigations could significantly improve the understanding of the petroleum system. The net effect of better publicly available data and more resolved geologic models is a reduction in risk, possibly enticing additional new exploration investment. 
The Susitna and Nenana basins have some potential for hosting undiscovered gas resources, and both are candidates for exploration under the terms of State-issued exploration licenses. Both remain underexplored, and insufficient data are available to predict the role these frontier basins may play in supplying energy to the Railbelt region. New geologic mapping and associated field studies along the margins of these basins would provide much needed constraints on the framework geology and hydrocarbon prospectivity. Furthermore, the collection of high resolution gravity and aeromagnetic surveys in key areas might yield important and relatively cost-effective insights into the structure, fill, and gas resource potential of the Susitna and Nenana basins. In order to stimulate future exploration by industry, the State could consider exercising its right to publicly release currently confidential seismic data to the public if and when exploration licenses terminate.

\section{Coal resource recommendations}

Many of the most prospective coal fields in the Railbelt development region-namely the Beluga, Matanuska, Lignite Creek and Healy Creek fields have a substantial history of coal exploration, and in some cases, coal extraction. The geology of these fields is reasonably well-defined, and further studies are unlikely to change the available assessments of their resource potential. Other fields, such as the Kenai, Susitna, and Broad Pass fields are either covered by thick deposits of glacial detritus or are of such low rank as to make further study unwarranted. There may be merit for additional reconnaissance-level studies of the perimeter of the Yentna field in the Susitna Basin, and the smaller Western Nenana, Tatlanika Creek, Wood River, Rex Creek, and Mystic Creek fields in the Nenana coal province. Such investigations may involve more detailed geologic mapping and stratigraphic studies to further assess the potential resources in those locations. These may be followed up by a thoughtful reconnaissance drilling program if results of surface investigations look promising.

\section{Unconventional oil and gas resource recommendations}

Coalbed methane. The abundance of biogenically produced gas in the greater Cook Inlet area indicates the potential for coalbed methane is high. However, additional exploration is required to confirm that the resource, if present, can be economically produced. Methods for separating methane from produced water and disposal of produced water in the region's cold climate must be addressed before this resource can be pursued to meet local energy needs.

Coal rank in the Nenana province is generally too low to suggest a significant methane resource is present and producable. However, additional surface and subsurface data is required to better understand the distribution, rank, and gas content of coal beds over large portions of the province.
Exploration for coalbed methane in the Healy Creek and Suntrana coal beds should consider areas removed from coal mining operations where depressurization from dewatering could hamper potential methane extraction.

Tight gas sands. The possibility exists for encountering fractured tight gas sands the lower part of the Tertiary section and in portions of the Mesozoic stratigraphic section in Cook Inlet. While producible hydrocarbons may be present in tight sands in these sections, exploring for this resource will require significant exploration investment and the use of emerging fracture inducing technology.. Recent State incentives encourage new exploration drilling to penetrate the Mesozoic section; these wells could provide much needed data on the tight gas resource potential in the deeper parts of the Cook Inlet basin. The presence of low porosity and permeability sandstone in the Nenana and Susitna basins is poorly constrained and the overall potential for tight gas reservoirs is largely unknown.

Shale gas. The potential for shale gas in the region is poorly known. The dearth of thermogenic gas recognized in conventional Tertiary reservoirs in Cook Inlet suggests the potential for shale gas in Tertiary units is low. Relatively few wells penetrate the middle Jurassic organic-rich rocks in the deeper part of the basin, although available data suggest modest potential for unconventional shale gas plays. State incentives for exploratory wells to drill into the Mesozoic may offer new insight into the potential for Jurassic shales to produce gas.

The nonmarine nature of the Susitna and Nenana basins are generally not conducive to regional shale gas plays. However too little is known, particularly from the deeper parts of the Nenana basin, to rule out the possibility of this resource type.

Gas hydrates. Due to the lack of extensive, continuous permafrost in most of the Railbelt region, the likelihood of finding gas hydrates are very low and doesn't warrant further consideration at this time.

\section{Geothermal resource recommendations}

The proximity of geothermal resources to population centers in the railbelt region has attracted significant attention, most recently manifest by the successful lease sale at Mt. Spurr. Recent State subsidized exploration activity by Ormat has improved our geologic understanding, but has thus far not demonstrated the existence of a geothermal resource. Detailed examination of the data collected during their 2011 exploration should guide any decisions on whether or not to invest in further drilling.

To determine whether anomalous thermal gradients in the Willow-Big Lake area are the result of a geothermal resource at depth, it is recommended that the State encourage additional exploration work in the area and if results warrant, conduct a geothermal lease sale. It is also recommended that the State continue to encourage exploration for geothermal 
resources in the Railbelt energy region by conducting additional geothermal lease sales within identified areas of interest.

The possible elevated geothermal gradient inferred from wells in the Willow-Big Lake area has long generated interest in a possible geothermal resource. However, this anomaly may be a drilling artifact; any further investment should await more definitive data.

\section{REFERENCES CITED AND SELECTED BIBLIOGRAPHY}

Adkison, W.L., Kelley, J.S., and Newman, K.R., 1975, Lithology and palynology of Tertiary rocks exposed near Capps Glacier and along Chuitna River, Tyonek Quadrangle, southern Alaska: U.S. Geological Survey Open-File Report 75-21, 58 p., 1 sheet.

Alaska Division of Geological \& Geophysical Surveys, 1990, Alaska's high-rank coals: Alaska Division of Geological \& Geophysical Surveys Information Circular 33, 36 p.

Alaska Division of Oil and Gas, 2007, Alaska oil and gas report, Alaska Division of Oil and Gas annual report.

Alaska Energy Authority (AEA), 2009, Alaska energy-A first step toward energy independence: Alaska Energy Authority, 245 pages. Available online at http://www. akenergyauthority.org/pdf files/AK Energy Final.pdf (accessed November 12, 2009).

Amato, J.M., Rioux, M.E., Kelemen, P.B., Gehrels, G.E., Clift, P.D., Pavlis, T.L., and Draut, A.E., 2007, U-Pb geochronology of volcanic rocks from the Jurassic Talkeetna Formation and detrital zircons from pre-arc and post-arc sequences-Implications for the age of magmatism and inheritance in the Talkeetna arc, in Ridgway, K.D., Trop, J.M., Glen, J.M.G., and O'Neil, J.M., eds, Tectonic Growth of a Collisional Continental Margin - Crustal Evolution of Southern Alaska: Geological Society of America Special Paper 431, p. 253-271.

Apell, G.A., 1944, Broad Pass Coal Reports: Alaska Territorial Department of Mines Miscellaneous Report 67-4, 2 p.

Barnes, F.F., 1966, Geology and coal resources of the BelugaYentna region, Alaska: U.S. Geological Survey Bulletin 1202-C, p. C1-C54, 4 sheets.

1967, Coal resources of Alaska: U.S. Geological Survey Bulletin 1242-B, p. B1-B36, 1 sheet, scale $1: 2,500,000$.

Barnes, F.F., and Cobb, E.H., 1959, Geology and coal resources of the Homer district, Kenai coal field, Alaska: U.S. Geological Survey Bulletin 1058-F, p. 217-260, 11 sheets, scale 1:2,400.

Barnes, F.F., and Sokol, Daniel, 1959, Geology and coal resources of the Little Susitna district, Matanuska coal field, Alaska: U.S. Geological Survey Bulletin 1058-D, p. 121-138, 1 sheet, scale 1:63,360.

Bradley, Dwight, Haeussler, Peter, O'Sullivan, Paul, Friedman, Rich, Till, Alison, Bradley, Dan, and Trop, Jeff,
2009, Detrital zircon geochronology of Cretaceous and Paleogene strata across the south-central Alaskan convergent margin, in Haeussler, P.J., and Galloway, J.P., Studies by the U.S. Geological Survey in Alaska, 2007: U.S. Geological Survey Professional Paper 1760-F, 36 p., http://pubs.usgs.gov/pp/1760/f/

Buffler, R.T., and Triplehorn, D.M., 1976, Depositional environments of the Tertiary coal-bearing group, central Alaska, in Miller, T.P., ed., Recent and ancient sedimentary environments in Alaska, Proceedings of the Alaska Geological Society Symposium held April 2-4, 1975, Anchorage: Alaska Geological Society, p. H1-H10.

Chena Hot Springs Resort, 2009a, Chena geothermal power plant-Project overview: Chena Hot Springs Resort website, "The Future Begins Today... at Chena Hot Springs Resort," http://www.yourownpower.com/ Power/\#ProjectOverview (accessed 8-16-12).

2009b, "Heat flow": Chena Hot Springs Resort website, http://www.chenahotsprings.com/geothermalexploration/ (accessed 8-16-12).

Chleborad, A.F., Yehle, L.A., Schmoll, H.R., and Gardner, C.A., 1980, Preliminary field geotechnical and geophysical logs from a drill hole in the Capps coal field, Cook Inlet region, Alaska: U.S. Geological Survey Open-File Report 80-393, 17 p., 6 sheets.

Chleborad, A.F., Yehle, L.A., Schmoll, H.R., Gardner, C.A., and Dearborn, L.L., 1982, Preliminary geotechnical and geophysical logs from drill hole 2C-80 in the Capps coal field, Cook Inlet region, Alaska: U.S. Geological Survey Open-File Report 82-884, 9 p., 2 sheets.

Claypool, G.E., Threlkeld, C.N., and Magoon, L.B., 1980, Biogenic and thermogenic origins of natural gas in Cook Inlet basin, Alaska: American Association of Petroleum Geologists Bulletin, v. 64, p. 1,131-1,139.

Conwell, C.N., Triplehorn, D.M., and Ferrell, V.M., 1982, Coals of the Anchorage Quadrangle, Alaska: Alaska Division of Geological \& Geophysical Surveys Special Report 17, 8 p., 4 sheets, scale 1:740.

Detterman, R.L., and Hartsock, J.K., 1966, Geology of the Iniskin-Tuxedni region, Alaska: U.S. Geological Survey Professional Paper 512, 78 p., 6 sheets, scale 1:63,360.

Dickinson, K.A., 1995, Geology, geochemistry, and uranium favorability of the Tertiary Kenai Group in the Susitna lowlands at the northern end of the Cook Inlet basin, Alaska: U.S. Geological Survey Bulletin 2098-A, 33 p.

Dobey, P.L., McGee, D.L., and DGGS Staff, 1976, Economic and geologic studies of the Beluga-Capps area and geologic resource occurrences in other areas of the proposed Cook Inlet land trade: Alaska Division of Geological \& Geophysical Surveys Alaska Open-File Report 94, 89 p., 1 sheet, scale 1:500,000.

Ehm, Arlen, 1983, Oil and gas basins map of Alaska: Alaska Division of Geological \& Geophysical Surveys Special Report 32, 1 sheet, scale 1:2,500,000. 
Finzel, E.S., Gillis, R.J., Ridgway, K.D., and LePain, D.L., 2009, Preliminary evaluation of basin margin exhumation and provenance of Cenozoic strata, Chuitna and Beluga rivers area, Cook Inlet forearc basin, Alaska: Alaska Division of Geological \& Geophysical Surveys Preliminary Interpretive Report 2009-4, 16 p.

Finzel, E.S., Trop, J.M., Ridgway, K.D., and Enkelmann, E., 2011, Upper plate proxies for flat-slab subduction processes in southern Alaska: Earth and Planetary Science Letters, v. 303, no. 3-4, p. 348-360.

Fitzgerald, P.G., Sorkhabi, R.B. Redfield, T.F., and Stump, E., 1995, Uplift and denudation of the central Alaska Range-A case study in the use of apatite fission track thermochronology to determine absolute uplift parameters: Journal of Geophysical Research, v. 100, p. 20,175-20,191.

Flores, R.M., Stricker, G.D., and Kinney, S.A., 2004, Alaska coal geology, resources, and coalbed methane potential: U.S. Geological Survey Digital Data Series 77, 140 p.

Flores, R.M., Stricker, G.D., and Roberts, S.B., 1994, Miocene coal-bearing strata of the Tyonek FormationBraided-stream deposits in the Chuit Creek-Chuitna River drainage basin, southern Alaska, in Till, A.B., and Moore, T.E., eds., Geologic studies in Alaska by the U.S. Geological Survey, 1993: U.S. Geological Survey Bulletin 2107, p. 95-114.

Flores, R.M., Stricker, G.D., and Stiles, R.B., 1997, Tidal influence on deposition and quality of coals in the Miocene Tyonek Formation, Beluga coal field, upper Cook Inlet, Alaska, in Dumoulin, J.A., and Gray, J.E., eds., Geologic studies in Alaska by the U.S. Geological Survey, 1995: U.S. Geological Survey Professional Paper 1574, p. $137-156$.

Frost, G.M., Barnes, D.F., and Stanley, R.G., 2003, Geologic and isostatic gravity map of the Nenana basin area, central Alaska: U.S. Geological Survey Geologic Investigations Series I-2543, 16 p.

Gillis, R.J., LePain, D.L., Ridgway, K.D., and Finzel, E.S., 2009, A reconnaissance view of an unnamed fault near Capps Glacier, northwestern Cook Inlet basin, and its potential as a regional-scale, basin-controlling structure: Alaska Division of Geological \& Geophysical Surveys Preliminary Interpretive Report 2009-3, 9 p.

Gillis, R.J., Wartes, M.A., and O’Sullivan, P.B., 2011, Preliminary findings from reconnaissance structural studies along the Bruin Bay fault system and adjacent areas, south-central Alaska: AAPG Pacific Section Meeting, Anchorage, AK, May 10, 2011: Alaska Division of Geological \& Geophysical Surveys, 1 sheet, http://dggs. alaska.gov/pubs/id/23403.

Gough, L.P., and Severson, R.C., 1983, Chemical analyses of native soil and vegetation samples, Capps coal field, Alaska: U.S. Geological Survey Open-File Report 83246,54 p.
Grantz, Arthur, Zietz, Isidore, and Andreasen, G.E., 1963, An aeromagnetic reconnaissance of the Cook Inlet area, Alaska: U.S. Geological Survey Professional Paper 316G, p. 117-134, 5 sheets, scale 1:1,000,000.

Grether, W.J., and Morgan, K.A, 1988, Exploration and hydrocarbon potential of interior basins, Alaska [abs.]: American Association of Petroleum Geologists Bulletin, v. 72, p. 191-192.

Hackett, S.W., 1976, Regional gravity survey of Beluga basin and adjacent area, Cook Inlet region, southcentral Alaska: Alaska Division of Geological \& Geophysical Surveys Alaska Open-File 100, 41 p.

1977, Gravity survey of Beluga basin and adjacent area, Cook Inlet region, southcentral Alaska: Alaska Division of Geological \& Geophysical Surveys Geologic Report 49, 31 p., 3 sheets.

Haeussler, P.J., Bruhn, R.L., and Pratt, T.L., 2000, Potential seismic hazards and tectonics of the upper Cook Inlet basin, Alaska, based on analysis of Pliocene and younger deformation: Geological Society of America Bulletin, v. 112 , p. 1,414-1,429.

Hartz, J.D., Kremer, M.C., Krouskop, D.L., Silliphant, L.J., Houle, J.A., Anderson, P.C., and LePain, D.L.; Decker, P.L., ed., 2009, Preliminary engineering and geological estimates of remaining Cook Inlet gas reserves: Alaska Division of Oil and Gas online report, http://dog.dnr.alaska.gov/ResourceEvaluation/Docum ents/Preliminary_Engineering_and_Geological_Evaluat ion_of_Remaining_Cook_Inlet_Gas_Reserves.pdf, 37 p.

Helmold, K.P., LePain, D.L., Wartes, M.A., Stanley, R.G., Gillis, R.J., Peterson, Shaun, and, Herriott, T.M., 2011, Reservoir potential of Tertiary and Mesozoic sandstones, Cook Inlet, Alaska: Pacific Section, American Association of Petroleum Geologists Meeting abstracts volume, http://www.alaskageology.org/documents/11/2011\%20 AAPG\%20Program_Covers_Program_REV_110412_730 AM.pdf

Kirschner, C.E., 1988, Map showing sedimentary basins of onshore and continental shelf areas, Alaska: U.S. Geological Survey Miscellaneous Investigations Series Map 1873, 1 sheet, scale 1:2,500,000.

Magoon, L.B., III, and Anders, D.E., 1992, Oil-to-source rock correlation using carbon-isotopic data and biological marker compounds, Cook Inlet-Alaska Peninsula, Alaska, in Moldowan, J.M., Albrecht, P., and Philip, R.P., eds., Biological Markers in Sediments and Petroleum: Englewood Cliffs, New Jersey, Prentice Hall, p. 241-274.

Magoon, L.B., III, Adkinson, W.L., and Egbert, R.M., 1976, Map showing geology, wildcat wells, Tertiary plant-fossil localities, K-Ar age dates, and petroleum operations, Cook Inlet area, Alaska: U.S. Geological Survey Miscellaneous Investigations Map I-1019, 3 sheets, scale $1: 250,000$. 
Martin, G.C., 1905; The petroleum fields of the Pacific Coast of Alaska, with an account of the Bering River coal deposits: U.S. Geological Survey Bulletin 250, 64 p.

1921, Preliminary report on petroleum in Alaska: U.S. Geological Survey Bulletin 719, 83 p., 5 sheets, scale $1: 125,000$.

Maurer, M.A., 1986, Chemical and biological water quality of selected streams in the Beluga coal area, Alaska: Alaska Division of Geological \& Geophysical Surveys Public Data File 86-51, 59 p.

Maurer, M.A., 1987, Chemical and biological water quality of selected streams in the Beluga coal area: Alaska Division of Geological \& Geophysical Surveys Report of Investigation 87-19, 49 p.

Maurer, M.A., and Toland, D.C., 1984, Water-quality data from the Beluga coalfield area: Alaska Division of Geological \& Geophysical Surveys Report of Investigation 84-27, 33 p.

May, R.R., and Warfield, R.S., 1957, Investigation of subbituminous-coal beds near Houston, westward extremity of Matanuska coal field, Alaska: U.S. Bureau of Mines Report of Investigations 5350, 20 p.

McGee, D.L., 1973, Coal reserve study, Chitina Beluga Capps area: Alaska Division of Geological \& Geophysical Surveys Alaska Open-File Report 30, 8 p., 4 sheets, scale $1: 5,820$.

McGee, D.L., and O'Connor, K.M., 1975, Mineral resources of Alaska and the impact of federal land policies on their availability — coal: Alaska Division of Geological \& Geophysical Surveys Alaska Open-File Report 51, 23 p.

Merritt, R.D., 1985a, Coal atlas of the Matanuska Valley, Alaska: Alaska Division of Geological \& Geophysical Surveys Public Data File 85-45, 270 p., 3 sheets, scale $1: 100,000$.

1985b, Coal atlas of the Nenana basin, Alaska: Alaska Division of Geological \& Geophysical Surveys Public Data File 85-41, 197 p., 6 sheets, scale 1 inch $=20$ feet. 1986, Coal geology and resources of the Matanuska Valley, Alaska: Alaska Division of Geological \& Geophysical Surveys Public Data File 86-76, 93 p.

1988, Alaska bituminous coal and anthracite: Alaska Division of Geological \& Geophysical Surveys Public Data File 88-15, 116 p.

1990, Coal resources of the Susitna lowland, Alaska: Alaska Division of Geological \& Geophysical Surveys Report of Investigation 90-1, 190 p., 3 sheets, scale $1: 250,000$.

Merritt, R.D., and Hawley, C.C., 1986, Map of Alaska's coal resources: Alaska Division of Geological \& Geophysical Surveys Special Report 37, 1 sheet, scale 1:2,500,000.

Merritt, R.D., Eakins, G.R., and Rawlinson, S.E., 1986, Coal and peat resource programs for Alaska: Alaska Division of Geological \& Geophysical Surveys Public Data File 86-70, 27 p.
Merritt, R.D., Lueck, L.L., Rawlinson, S.E., Belowich, M.A., Goff, K.M., Clough, J.G., and Smith, L.R., 1987, Coal resource assessment and mapping project, south Kenai Peninsula: Alaska Division of Geological \& Geophysical Surveys Public Data File 87-15, 133 p., 14 sheets, scale 1 centimeter $=1$ meter.

Meyer, J.F., Jr., 2008, Oil and gas basin resource series for maps of Interior Alaska - Copper River basin, Holitna basin, Minchumina basin, Nenana basin, and Susitna basin: Alaska Division of Oil \& Gas Basin Resource Series, 24 plates, scale 1:250,000 and 1:1,000,000.

Meyer, J.F., and Krouskop, D.L., 1986, Preliminary gravity data of the Minchumina Basin, south-central Alaska: Alaska Division of Geological \& Geophysical Surveys Report of Investigation 86-1, 14 p., 2 sheets, scale 1:500,000.

Motyka, R.J., Moorman, M.A., and Liss, S.A., 1983, Geothermal resources of Alaska: Alaska Division of Geological \& Geophysical Surveys Miscellaneous Publication 8, 1 sheet, scale 1:2,500,000.

PacRim Coal, 2005, Development status, Chuitna Coal Project, presentation to Alaska Support Industry Alliance, November 22, Kenai, Alaska, http://www.cookinletoilandgas.org/PowerPoint\%20Presentations/PDF\%20 Versions/Alliance\%20Presentation.pdf

Petroleum News, 2009, Drillers near target at Nenana gas well: Petroleum News, v. 14, no. 31, week of August 2, 2009.

Petrotechnical Resources Alaska, and Doyon, Ltd., undated, Nenana basin, Alaska, (poster summarizing petroleum potential).

Plafker, George, Moore, J.C., and Winkler, G.R., 1994, Geology of the southern Alaska margin, in Plafker, George, and Berg, H.C., eds., The Geology of Alaska: Boulder, Colorado, Geological Society of America, The Geology of North America, v. G-1, p. 389-449.

Plafker, George, Naeser, C.W., Zimmermann, R.A., Lull, J.S., and Hudson, Travis, 1992, Cenozoic uplift history of the Mount McKinley area in the central Alaska Range based on fission-track dating, in Bradley, D.C., and DuselBacon, Cynthia, eds., Geologic studies in Alaska by the U.S. Geological Survey, 1991: U.S. Geological Survey Bulletin 2041, p. 202-212.

Reed, B.L., and Lanphere, M.A., 1969, Age and chemistry of Mesozoic and Tertiary plutonic rocks in south-central Alaska, Geological Society of America Bulletin, v. 80, p. 23-44.

Reed, B.L., and Nelson, S.W., 1980, Geologic map of the Talkeetna Quadrangle, Alaska: U.S. Geological Survey Miscellaneous Investigations 1174, 15 p., 1 sheet, scale $1: 250,000$.

Renshaw, Daniel, 1977, Memorandum to Cleland Conwell concerning Usibelli Coal Mine reserves, unpublished correspondence, in Merritt, R.D., 1986, Coal geology and 
resources of the Nenana Basin, Alaska: Alaska Division of Geological \& Geophysical Surveys Public Data File 86-74, $4 \mathrm{p}$.

Ridgway, K.D., Thoms, E.E., Layer, P.W., Lesh, M.E., White, J.M., and Smith S.V., 2007, Neogene transpressional foreland basin development on the north side of the central Alaska Range, Usibelli Group and Nenana Gravel, Tanana basin, in Ridgway, K.D., Trop, J.M., Glen, J.M.G., and O'Neil, J.M., eds, Tectonic Growth of a Collisional Continental Margin - Crustal Evolution of Southern Alaska: Geological Society of America Special Paper 431, p. 507-547.

Sanders, R.B., 1981, Coal resources of Alaska, in Rao, P.D., and Wolff, E.N., eds., Focus on Alaska's Coal '80: Alaska Coal Conference, 2nd, Fairbanks, 1980, Proceedings, University of Alaska Mineral Industry Research Laboratory Report 50, p. 11-31.

Scully, D.R., Krumhardt, A.P., and Kernodle, D.R., 1980, Data from a hydrologic reconnaissance of the Beluga, Peters Creek, and Healy coal areas, Alaska: U.S. Geological Survey Open-File Report 80-1206, 54 p.

Stanley, R.G., Charpentier, R.R., Cook, T.A., Houseknecht, D.W., Klett, T.R., Lewis, K.A., Lillis, P.G., Nelson, P.H., Phillips, J.D., Pollastro, R.M., Potter, C.J., Rouse, W.A., Saltus, R.W., Schenk, C.J., Shah, A.K., and Valin, A.C., 2011, Assessment of undiscovered oil and gas resources of the Cook Inlet region, south-central Alaska, 2011: U.S. Geological Survey Fact sheet 2011-3068, 2 p.

Stanley, R.G., Flores, R.M., and Wiley, T.J., 1992, Fluvial facies architecture in the Tertiary Usibelli Group of Suntrana, central Alaska, in Bradley, D.C., and Ford, A.B., eds., Geologic studies in Alaska by the U.S. Geological Survey, 1990: U.S. Geological Survey Bulletin 1999, p. 204-211.

Stanley, R.G., McLean, Hugh, and Pawlewicz, M.J., 1990, Petroleum source potential and thermal maturity of the Tertiary Usibelli Group of Suntrana, Alaska, in Dover, J.H., and Galloway, J.P., eds., Geologic studies in Alaska by the U.S. Geological Survey, 1989: U.S. Geological Survey Bulletin 1946, p. 65-76.

Stevens, C.C., 1971, A provenance study of the Tertiary sandstones in the Healy Creek and Lignite Creek coal basins, Nenana coal field, Alaska: College, Alaska, University of Alaska Fairbanks, M.S. Thesis, 122 p.

Stone, R.W., 1906, Coal fields of the Kachemak Bay region: U.S. Geological Survey Bulletin 277, p. 53-73.

Swenson, R.F., 2003, Introduction to Tertiary tectonics and sedimentation in the Cook Inlet basin, in Dallegge, T.A., compiler, 2001 guide to the petroleum, geology, and shallow gas potential of the Kenai Peninsula, Alaska: Alaska Division of Geological \& Geophysical Surveys Miscellaneous Publication 128, $70 \mathrm{p}$.

Trop, J.M., and Ridgway, K.D., 2007, Mesozoic and Cenozoic tectonic growth of southern Alaska—A sedimentary basin perspective, in Ridgway, K.D., Trop, J.M., Glen, J.M.G., and O'Neil, J.M., eds, Tectonic growth of a collisional continental margin-Crustal evolution of southern Alaska: Geological Society of America Special Paper 431, p. 55-94.

Turner, D.L., and Wescott, E.M., 1982, A preliminary investigation of the geothermal energy resources of the lower Susitna basin: Geophysical Institute, University of Alaska Report UAG R-287, 50 p., 3 plates.

Usibelli Coal Mine, 2009, company web page, http://www. usibelli.com/Mine_sites.php

Wahrhaftig, Clyde, 1944, Coal deposits of the Costello Creek basin, Alaska: U.S. Geological Survey Open-File Report 44-26, 7 p., 1 sheet.

1951, Geology and coal deposits of the western part of the Nenana coal field, Alaska, in Barnes, F.F., Wahrhaftig, C.A., Cobb, E.H., Freedman, Jacob, Hickcox, C.A., and Hopkins, D.M., 1951, Coal investigations in south-central Alaska: U.S. Geological Survey Bulletin 963-E, p. 137-209, 10 sheets.

1969, The coal-bearing group in the Nenana coal field, Alaska: U.S. Geological Survey Bulletin 1274-D, p. D1-D30.

Wahrhaftig, Clyde, 1987, The Cenozoic section at Suntrana, Alaska, in Hill, M.L., ed., Geological Society of America, Cordilleran Section, Centennial Guide, v. 1, p. 445-450. 1994, Maps of physiographic divisions of Alaska, 1 sheet, scale 1:2,500,000 in Plafker, George, and Berg, H.C., eds., The Geology of Alaska: Boulder, Colorado, Geological Society of America, The Geology of North America, v. G-1.

Warfield, R.S., 1959, Summary of coal drilling results, Beluga River coal field, 1959: Alaska Territorial Department of Mines Miscellaneous Report 84-1, 22 p.

Wilson, F.H., 1985, The Meshik Arc-An Eocene to earliest Miocene magmatic arc on the Alaska Peninsula: Alaska Division of Geological \& Geophysical Surveys Professional Report 88, 14 p.

Wolfe, J.A., and Toshimasa, T., 1980, The Miocene Seldovia Point flora from the Kenai Group, Alaska: U.S. Geological Survey Professional Paper 1105, 52 p. 